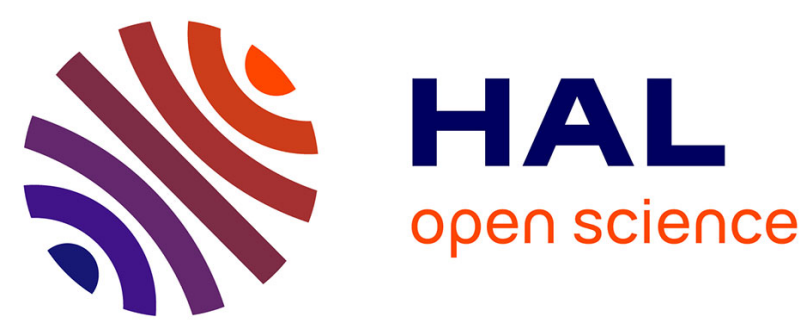

\title{
The impact of the end-Ordovician glaciation on sediment routing systems: A case study from the Meseta (northern Morocco)
}

J.-F. Ghienne, A. Benvenuti, M. El Houicha, F. Girard, E. Kali, Y. Khoukhi, C. Langbour, T. Magna, J. Míková, A. Moscariello, et al.

\section{To cite this version:}

J.-F. Ghienne, A. Benvenuti, M. El Houicha, F. Girard, E. Kali, et al.. The impact of the endOrdovician glaciation on sediment routing systems: A case study from the Meseta (northern Morocco). Gondwana Research, 2018, 63, pp.169-178. 10.1016/j.gr.2018.07.001 . hal-01898541

\section{HAL Id: hal-01898541 https://hal.science/hal-01898541}

Submitted on 15 Mar 2019

HAL is a multi-disciplinary open access archive for the deposit and dissemination of scientific research documents, whether they are published or not. The documents may come from teaching and research institutions in France or abroad, or from public or private research centers.
L'archive ouverte pluridisciplinaire HAL, est destinée au dépôt et à la diffusion de documents scientifiques de niveau recherche, publiés ou non, émanant des établissements d'enseignement et de recherche français ou étrangers, des laboratoires publics ou privés. 
1 The impact of the end-Ordovician glaciation on sediment routing systems: A case

2 study from the Meseta (northern Morocco)

3

4 J.-F. Ghienne ${ }^{1}$, A. Benvenuti ${ }^{2}$, M. El Houicha ${ }^{3}$, F. Girard ${ }^{4}$, E. Kali ${ }^{1}$, Y. Khoukhi ${ }^{5}$, C.

5 Langbour ${ }^{1}$, T. Magna ${ }^{6}$, J. Míková6 , A. Moscariello², K. Schulmann ${ }^{1,6}$

6

7 Gondwana Research, 63, 169-178. Doi: 10.1016/j.gr.2018.07.001

8

9

10 1'Institut de Physique du Globe de Strasbourg, EOST - UMR7516, CNRS/Université de

11 Strasbourg, 1 rue Blessig, F-67084 Strasbourg, France

12 2University of Geneva, 13 rue des Maraîchers, CH-1211, Switzerland

13 33niversité Chouaib Doukkali, El Jadida, Morocco

$14{ }^{4}$ UMR5243, 60 place E. Bataillon, F-34095 Montpellier, France

15 5Université Mohamed Ier, Oujda, Morocco

$16{ }^{6}$ Czech Geological Survey, Klárov 3, CZ-11821 Prague, Czech Republic

18 Corresponding author:

19 Jean-François Ghienne, Institut de Physique du Globe de Strasbourg, EOST - UMR7516,

20 CNRS/Université de Strasbourg, 1 rue Blessig, F-67084 Strasbourg, France

21 ghienne@unistra.fr 


\section{ABSTRACT}

Assessment of sediment redistribution by end-Ordovician ice sheets is crucial for the reconstruction of Lower Paleozoic source-to-sink patterns. Focussing on the ice-distal, deepwater Tazekka depocenter (Moroccan Meseta), we thus performed a provenance study that combined whole-rock geochemistry, petrography and insights from highresolution detrital zircon ages. The results show that the glacigenic sediments are compositionally — mineralogically and geochemically - more mature than preglacial strata. This observation points to a preferential cannibalization of the "great Lower Paleozoic quartz-rich sandstone sheet", with a limited input of first-cycle, far-travelled clastic sediments. Differentiation of glacial units is not straightforward, yet the glaciation acme is typified by a highly mature sedimentary source and an age spectrum lacking Mesoproterozoic zircon grains, both features strongly indicating derivation from the Cambrian-Lower Ordovician cover of the Tuareg Shield. More regional sources are expressed during the earlier glaciation stages, during which lowstand remobilisations unrelated to subglacial erosion are also suspected. Subordinate but notable late Tonian $(\sim 0.8 \mathrm{Ga})$ and latest Stenian to early Tonian $(\sim 1 \mathrm{Ga})$ zircon populations are also evidenced in Morocco, which may have implications for future paleogeographic reconstructions.

(1)

\section{Keywords}

sediment cannibalization, glacial erosion, zircon geochronology, source-to-sink, Hirnantian, peri-Gondwana 


\section{Introduction}

The end-Ordovician glaciation culminated in the growth of a large ice sheet over

Gondwana (Le Heron and Craig, 2008; Ghienne et al., 2014; Pohl et al. 2016). From West

52

Africa to Arabia, ice-sheet divides and flow orientations were not necessarily superimposed on preglacial fluvial drainage systems (e.g., Meinhold et al., 2013); the latter serving as guidelines for peri-Gondwana paleotectonic reconstruction based on detrital zircon geochronology (e.g., Pastor-Galán et al., 2013; Shaw et al., 2014). In particular, the assessment of Mesoproterozoic zircon grains in NW Africa is of interest (Avigad et al., 2012; Pratt et al., 2015). As such ages are generally regarded in the north African context as marking a source originating in the Sahara metacraton (NE Africa; Henderson et al., 2015; Chelle-Michou et al., 2017), multi-stage sediment recycling events (see discussion in Andersen et al., 2016) and potential mixing linked to the endOrdovician glaciation may have severely altered the true significance of zircon provenance. Alternatively, glacially fed routing systems can introduce, or enhance, the contribution of far-travelled sediment sources that were absent or subordinate in preglacial watersheds (Doornbos et al., 2009; Hofmann et al. 2015; Gürsu et al., 2018). For instance, the massive arrival of $>2.3$ Ga zircon grains that has been detected in the Upper Ordovician strata of the ice-proximal reaches of the glaciated platform in the southern Hoggar (Linnemann et al., 2011) might be a consequence of the reorganization of sediment dispersal trends owing to glaciation. Actually, the degree to which the endOrdovician glaciation impinged on the Paleozoic dispersal systems of the Gondwana remains unknown (Avigad et al., 2012, 2017).

At the scale of NW Africa, ice flows departing from an oversimplified centrifugal scheme, which in addition does not fully conform to the preglacial fluvial transport directions (Fig. 1), should be supported by changes in sediment provenance preserved 
in the glacial stratigraphic record. We have performed a systematic and detailed provenance study focusing on the glacigenic sediments of the Tazekka Massif (northern Morocco), a representative area of ice-distal platform segments in end-Ordovician reconstructions (Le Heron et al., 2007). As such, the Tazekka depositional system can be viewed as the final sink of the end-Ordovician, NW African glacial routing system. This new dataset aids in deciphering the impact of the glaciation on the continental-scale sediment dispersal, a resurgence of which may have occurred well after the glacial event through recycling (Pratt et al., 2015). Also, given that the end-Ordovician glaciation corresponds to a polyphase climatic event (Ghienne et al., 2007a, 2014), any clues from high-resolution provenance studies may help to delineate individual advance-retreat cycles of the end-Ordovician ice sheets, provided they relate to distinct sediment routing systems throughout the north-Gondwana platform. We tested if geochronological studies on glacigenic sediments could constitute a valuable tool, which, beyond paleogeographical purposes, could help to better constrain stratigraphic correlations within the end-Ordovician glacial record, e.g. from relatively ice-distal area (Morocco, Europe) toward more internal domains of the north-Gondwana platform (from Mauritania to Chad); such correlations being a pre-requisite for robust paleoclimatic scenarios.

\section{Geological setting}

\subsection{Study area}

The Tazekka Massif is a part of the Moroccan Meseta (Fig. 1), the pre-Variscan configuration of which remains unclear, yet generally positioned NW of the Anti-Atlas between the Gondwana landmass and an undefined continental margin (Hoepffner et al., 2005; Michard et al., 2010; Chopin et al., 2014; Pérez-Cáceres et al., 2017). Above a 


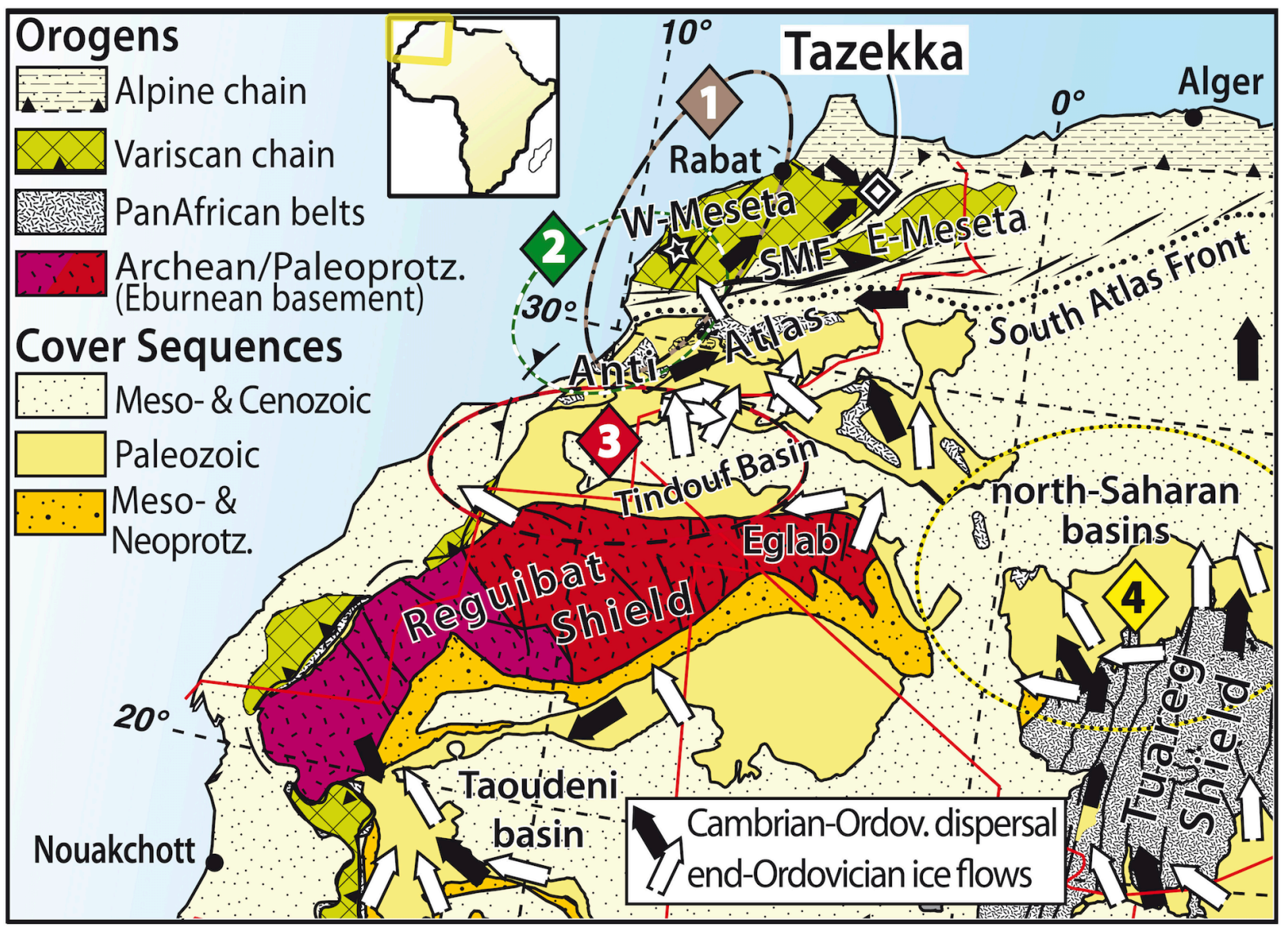

Figure 1. Geological setting (coordinates of the main section in the Tazekka inlier: c. $33,9588^{\circ} \mathrm{N}, 4,3802^{\circ} \mathrm{W}$ ). The Paleozoic configuration was slightly different, owing to poorly constrained Variscan offsets (e.g., along the South Meseta Fault, SMF). The star positions the westernmost Meseta (samples NF01 \& 15DL12; Fig. 6). Numbers in diamonds refer to zircon sources (see Figs. 2, 5 and 7). Ice flows orientations mainly from Ghienne et al. (2007), Deschamps et al., (2013), Dietrich et al., in press. 
preglacial, essentially fine-grained succession (Tehar el Brehl Fm.), there is a thick glacigenic sandstone wedge forming the Tifarouine Fm., which was entirely deposited beyond the end-Ordovician ice fronts (Le Heron et al., 2007, 2008). In the framework of this study, supplementary sections were logged in and around the type area. Our revised stratigraphy allows us to outline five informal stratigraphic members (Fig. 2), the lateral extent of which is in excess of $20 \mathrm{~km}$. Medium-grained sandstones and mudstone interbeds of Mbs 1 and 4 are interpreted as basin-floor turbiditic lobe complexes while amalgamated coarse-grained sandstone sheets of Mbs 3 and 5 represent oversupplied turbiditic systems reflecting two major glacial advances. Glacimarine influence characterizes Mb. 2 (channels, debris-flows, ice-rafted debris), as well as thin interbeds in Mbs 4 and 5. Silurian shales and cherts mark the post-glacial onset of outer shelf conditions. Limited paleocurrent data in turbiditic deposits highlight relatively uniform flows through time from the NW, the $\mathrm{W}$ or the SW, yet the original orientations potentially altered by Variscan thrust tectonics (Hoepffner et al., 2005) — are admittedly unknown.

\subsection{Paleoglacial setting}

From the nearby ice-proximal Anti-Atlas record (Fig. 1), it has been shown that Late Katian and lower Hirnantian lowstand wedges characterize the early glaciation phases, during which glaciers did not reach Morocco (Loi et al. 2010; Ghienne et al., 2014). In contrast, several advance-retreat cycles of the ice sheets are recognized during the late Hirnantian glaciation maximum associated with ice flows from the SE-SSE or from the WNW-WSW (Ghienne et al., 2007a, Le Heron, 2007; Le Heron et al., 2007; Ghienne et al., 2014; Ravier et al., 2015; Dietrich et al., in press). However, temporal correlation of this sequence of events with the Tazekka record is still unresolved. 
125 flowed over Upper Ordovician sediments. However, further toward the SW, S or SE, they eroded Lower Ordovician to Cambrian strata (Ghienne et al., 2007 a, b). As shown by

127 rare exotic pebbles — mainly granites, less mafic or metamorphic lithologies- in

128 glacimarine deposits, the basement has directly sourced the glacigenic sediments, at

129 least locally (Fig. 1; Eglab area, Rognon et al., 1972).

\section{Methods}

\subsection{Geochemical and petrographic analysis}

133 Whole-rock geochemical (XRF and LA-ICP-MS) and automated petrographic (QEMSCAN)

134 analysis were performed on seven samples from the Tehar-el-Brehl Fm. and on 36

135 samples distributed through the five members of the Tifarouine Fm. (19 sandstones, five

136 diamictites and 12 mudstones; Fig. 2). Major element compositions were determined by

137 X-ray fluorescence (XRF) with a PANalytical Philips PW2400 spectrometer at the

138 University of Lausanne. The trace-element concentrations of whole rocks were

139 measured on glass beads by laser ablation inductively-coupled-plasma mass

140 spectrometry (LA-ICP-MS) with an Agilent 7700 laser ablation system at the University

141 of Lausanne. Data were reduced with LAMTRACE software (Longerich et al. 1996;

142 Jackson 2008). Automated mineral characterization was performed using an FEI

143 QEMSCAN@ Quanta 650F facility installed at the Department of Earth Sciences,

144 University of Geneva equipped with two Bruker QUANTAX light-element energy

145 dispersive X-ray spectrometers at high vacuum, accelerating voltage of $25 \mathrm{kV}$, and probe

146 current of $10 \mathrm{nA}$ on the carbon-coated polished thin sections. Data processing was

147 performed using the FEI iDiscover software package. The effect of weathering,

148 diagenetic, hydraulic sorting, and source rock composition over the compositional 


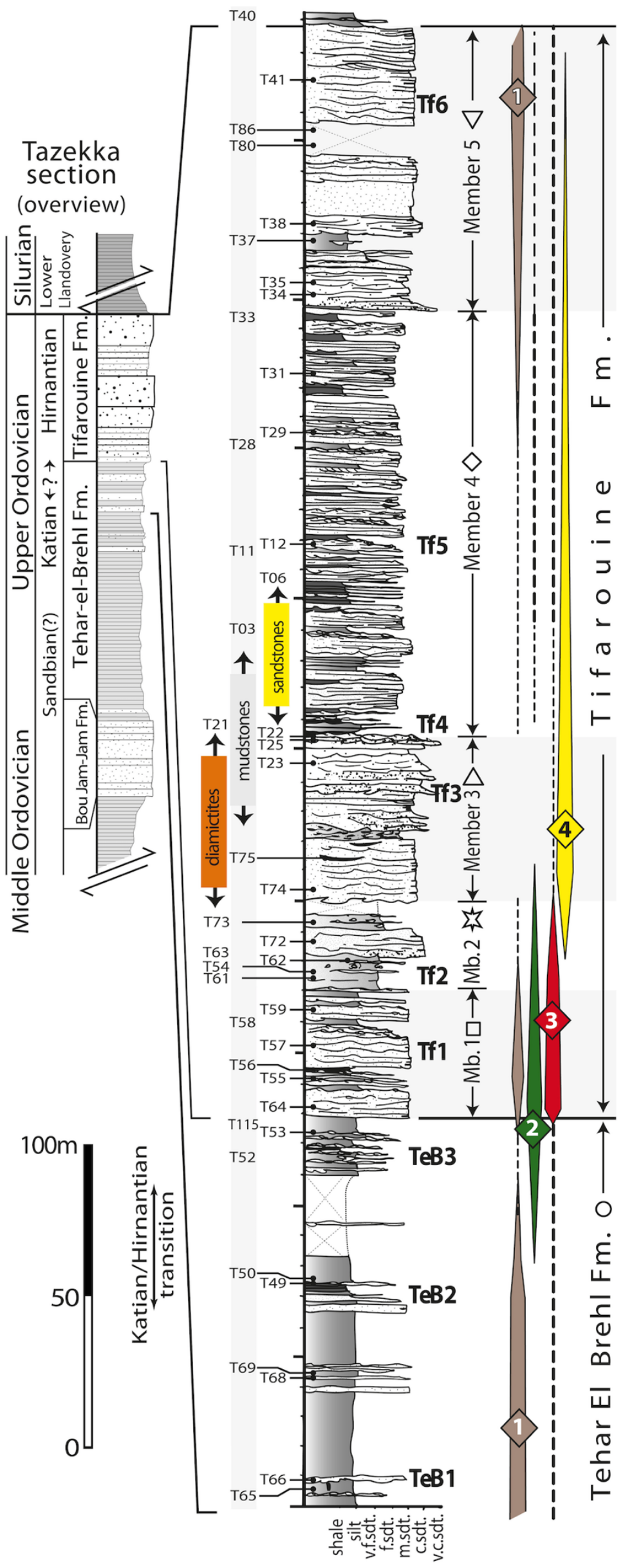

Figure 2. Synthetic section of the Tazekka succession, built from the compilation of five sedimentological logs. On the left, position of samples on which geochemical and petrographic analyses have been performed (Figs. 3 \& 4). Samples used for U-Pb geochronology of detrital zircon populations are positioned on the right (TeB 1-3 and Tf 16 ; probability plots of Fig. 5). On the right: the inferred scenario for source development (see text for details). Symbols (star, triangle...) associated to stratigraphic units are linked to codes used in figures 3 and 4. 
results of the investigated samples were investigated following the procedures described in McLennan et al. (1993, 2003), Fralick (2003) and Nesbitt (2003).

\section{2. $U-T h-P b$ Geochronology}

Three samples from the Tehar el Brehl Fm. (TeB 1-3) and six samples from the Tifarouine Fm. (Tf 1-6) were processed. Detrital zircon grains were separated from several kilograms of samples by sorting, magnetic separation and conventional heavy liquid separation. The final zircon fraction was purified by handpicking in ethanol using a binocular microscope. Zircon samples were mounted in epoxy resin, polished and imaged by cathodoluminiscence to reveal the internal structures of zircon grains by employing a Tescan MIRA 3GMU electron microprobe (Oxford Instruments), housed at the Czech Geological Survey.

The U-Th-Pb dating was performed using an Analyte Excite 193 nm excimer laser ablation system (Teledyne CETAC, Omaha, Nebraska, USA), equipped with a two-volume HelEx ablation cell, in tandem with an Agilent 7900x ICPMS (Agilent Technologies Inc., Santa Clara, USA), housed at the Czech Geological Survey. Samples were ablated in He atmosphere $\left(0.8 \mathrm{lmin}^{-1}\right)$ at a pulse repetition rate of $5 \mathrm{~Hz}$ using a spot size of $25 \mu \mathrm{m}$ and laser fluence of $7.59 \mathrm{~J} \mathrm{~cm}^{-2}$. Each measurement consisted of $20 \mathrm{~s}$ of blank acquisition followed by 40 s sample signal acquisition. The masses 202, 204, 206, 207, 208, 232 and 238 were collected using the SEM detector, with one point per mass peak and the respective dwell times of 10,10,15, 30, 20, 10 and 15 ms per mass (total sweep time of $0.134 \mathrm{~s}$ ). Instrumental drift was monitored by repeat measurements of 91500 reference zircon (Wiedenbeck et al. 1995) after every 20 unknowns. Data deconvolution using the Iolite software followed the method described by Paton et al. (2010), including an 'on 
peak' gas blank subtraction followed by correction for laser-induced elemental

174 fractionation (LIEF) by comparison with the behavior of the 91500 reference zircon

175 (Wiedenbeck et al. 1995). The weighted mean concordia age of $1062.8 \pm 2.5 \mathrm{Ma}(\mathrm{n}=$

$176420,2 \sigma$ ) was obtained for 91500 reference zircon. In addition zircon reference samples

177 GJ-1 ( 609 Ma; Jackson et al. 2004) and Plešovice (337 Ma; Sláma et al. 2008) were

178 analysed periodically during this study and yielded the concordia ages of $607.9 \pm 2.8 \mathrm{Ma}$

$179(\mathrm{n}=170,2 \sigma)$ and $338.2 \pm 2.3 \mathrm{Ma}(\mathrm{n}=320,2 \sigma)$, respectively. We have used decay

180 constants incorporated in the Isoplot software (Ludwig, 2012), which are from Jaffey et

181 al. (1971). No common Pb correction has been applied to the data due to the high level

182 of isobaric Hg interferences derived from the carrier gases. We did not apply the

$183{ }^{207} \mathrm{~Pb} /{ }^{206} \mathrm{~Pb}$ criteria for older zircon grains, but the information is included in the data

184 table (Supplementary Material). Instead, the Concordia function of Isoplot software was

185 used for detrital zircon probability plots, which calculates the concordia age based on

186 the ${ }^{206} \mathrm{~Pb} /{ }^{238} \mathrm{U}$ and ${ }^{207} \mathrm{~Pb} /{ }^{235} \mathrm{U}$ ratios and their errors and which yields a more precise

187 mean age than that commonly obtained using either ratio alone.

\section{Results}

\subsection{Insights from petrography and geochemistry}

191 Sandstones share a medium-high compositional maturity while mudstones are

192 relatively enriched in K-rich clay minerals. Glacigenic sandstones are dominated by

193 quartz ( $>70$ modal \%, but generally > 80\%) and depleted in feldspars; high values of the

194 Chemical Index of Alteration (Nesbitt and Young, 1982) from 65 to 75 and, especially, of

195 the Plagioclase Index of Alteration ( $>65$ but more usually > 90; Fedo et al. 1995), prove

196 intense weathering in the source area (Fig. 3A). Preglacial sandstones are characterized

197 by higher proportions of detrital sodic feldspars (up to 17 modal \%) suggesting less 

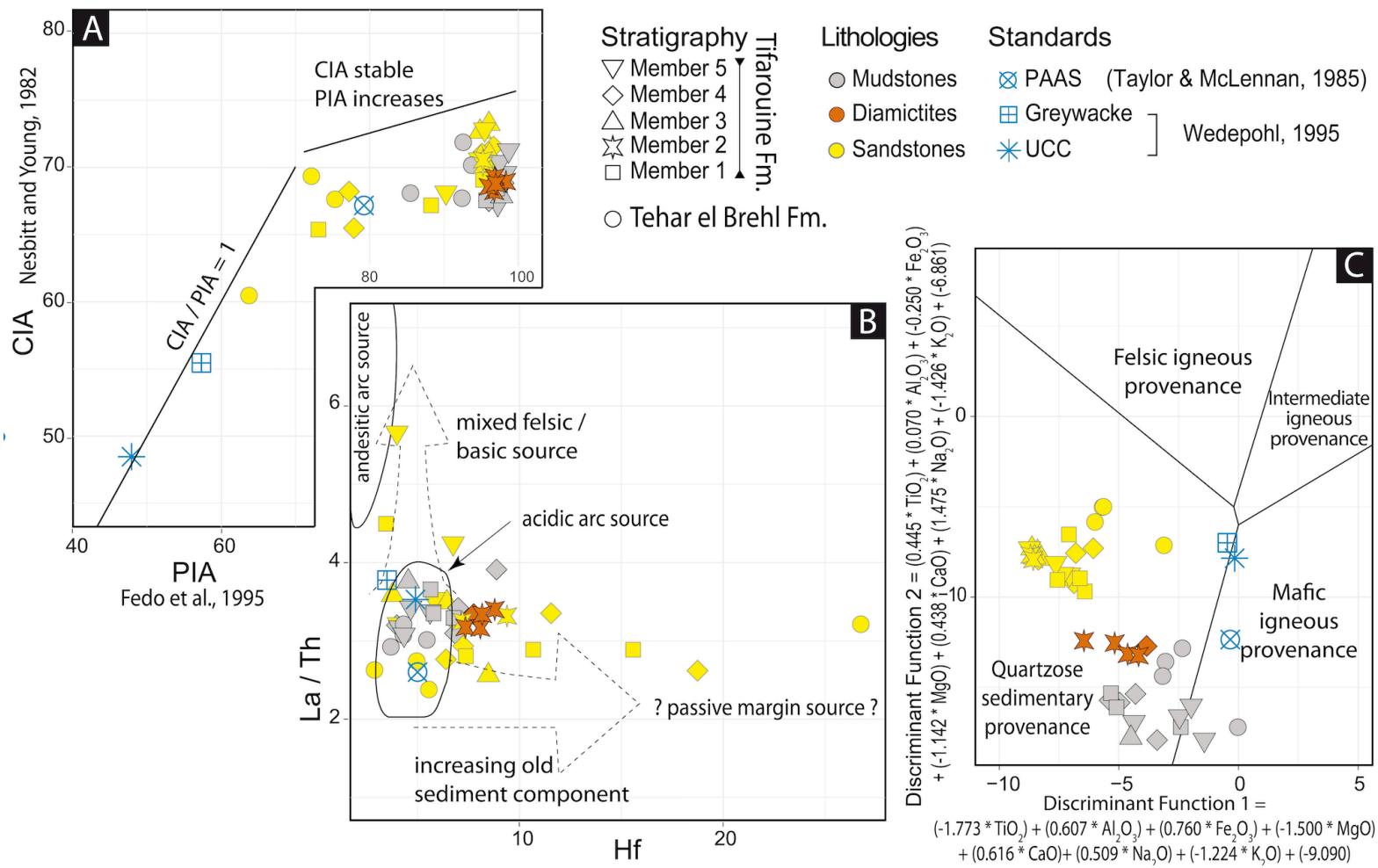
$+(0.616 * \mathrm{CaO})+(0.509 * \mathrm{Na}, 0)+(-1.224 * \mathrm{~K}, 0)+(-9.090)$

Figure 3. Geochemical results. A: Bivariate diagram between Chemical (CIA, Nesbitt \& Young, 1982) and Plagioclase (PIA, Fedo et al., 1995) Indexes of Alteration. B:

Provenance characterization diagram (Floyd \& Leveridge, 1987). C: Discrimination diagram for sedimentary provenance based on major elements (Roser \& Korsch, 1988). 

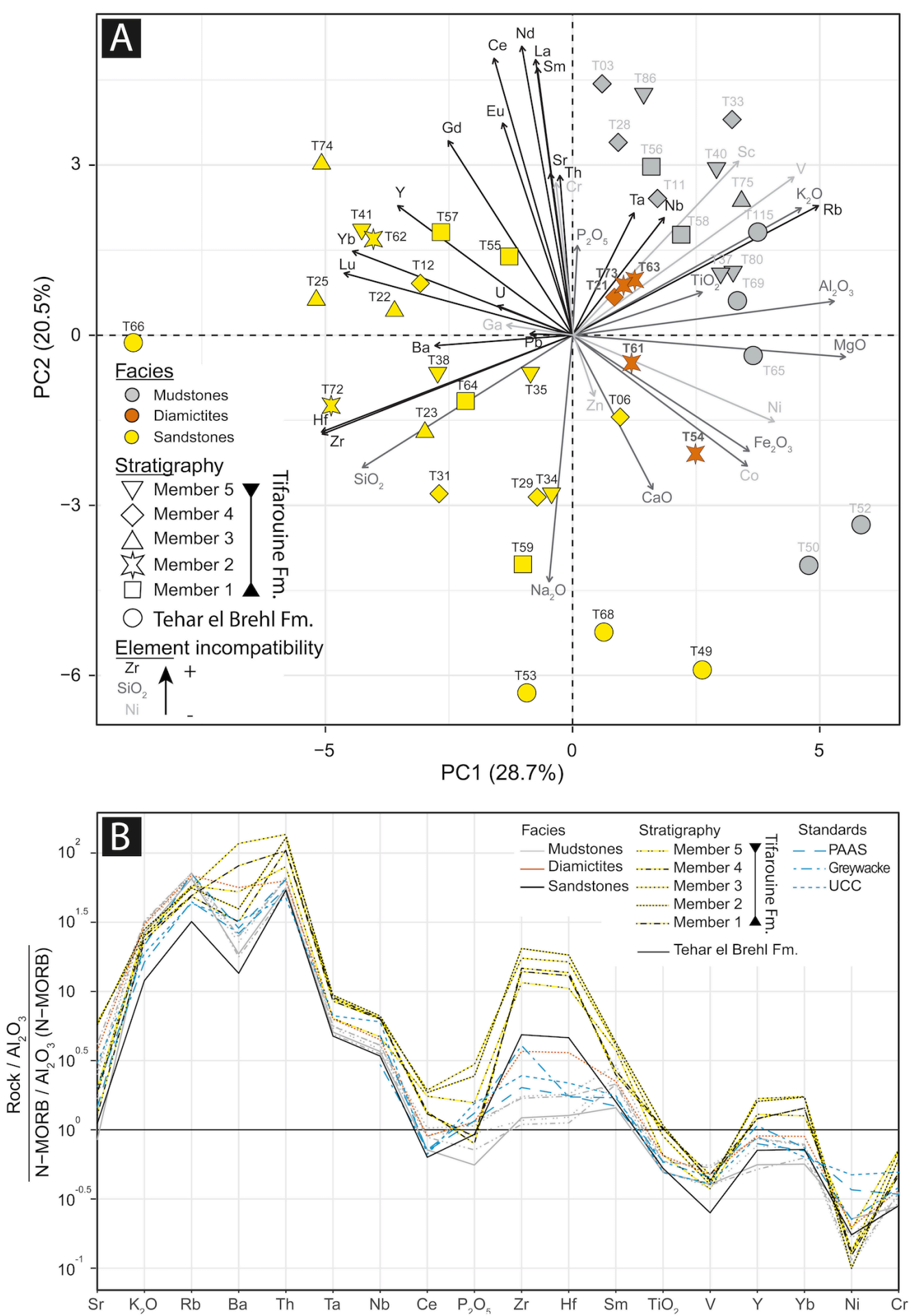

Figure 4. A: Principal component analysis of prevalently immobile elements. The two major components describe roughly half of the total variance of the geochemical composition of the investigated deposits. $\mathrm{Na}_{2} \mathrm{O}$ and $\mathrm{CaO}$ (largely present in feldspars) and compatible elements correlate positively with the deposits of Tehar-elBrehl Fm. Incompatible elements correlate with those of the Tifarouine Fm. Mudstones and sandstones are separated along a direction perpendicular to the one that delimits the stratigraphic formations, indicating that grain size does not influence any unit differentiation based on geochemistry. B: Spider diagrams of selected element concentrations of preglacial and glacial deposits normalized to $\mathrm{Al}_{2} \mathrm{O}_{3}$ and N-MORB. High concentrations of incompatible elements, and LILE ( $\mathrm{Rb}, \mathrm{Cs}, \mathrm{Sr}, \mathrm{Ba})$ in particular, compared to the compatible elements suggest that the initial source rock composition of the investigated deposits was acidic. 
weathered preglacial sources. Notable recycling processes of sedimentary deposits are suggested by the higher-than-average content in sandstones of heavy minerals enriched in Zr-Hf, especially glacigenic sandstones, compared to the greywacke and UCC standard values (Fig. 4B). The greater maturity of the glacigenic sediments, for which a higher degree of chemical alteration is unlikely (Bahlburg and Dobrzinski 2011), highlights a re-organization in sediment provenance at the glaciation onset. A discriminant diagram based on major elements (Roser and Korsch, 1988) confirms that a sedimentary source was prevalent (Fig 3C). The compositional difference between the Tehar-el-Brehl and Tifarouine Fms. must be principally related to distinct composition of the sedimentary sources. This is in line with a principal component analysis of major and trace elements concentrations (Fig. 4A) showing preferential enrichment of incompatible elements in glacigenic deposits, which suggests that the source rocks of the glacigenic sediments were originally derived from more evolved magmatic rocks. concentrations of elements such as $\mathrm{Hf}$ in individual sandstone samples of Mbs $1 \& 4$ (Fig. 3B). Interestingly, abundance shifts are not reflected by a higher maturity of those samples and are recorded in both sandstones and mudstones. This indicates a preferential reworking of strata that were already enriched in heavy minerals (zircon, monazite), for instance coastal placers, which are recurrently observed in Ordovician nearshore deposits (e.g., Pistis et al., 2016). Diamictites are plotted in between sandstones and mudstones (Figs. 3C and 4A), indicating grain-size mixing rather than a

219 specific sourcing. Sandstones in Mbs 2 and 3 are associated with the most mineralogically and geochemically mature source composition. This is particularly

221 apparent in Figs. 3A, 3C and 4B where these sandstones have, for instance, and on 222 average, (i) higher indices of alteration, (ii) parameters indicative of a sedimentary 
source largely dominated by a quartzose provenance, and (iii) higher concentrations of $\mathrm{P}_{2} \mathrm{O}_{5}, \mathrm{Hf}, \mathrm{Zr}, \mathrm{Yb}$. This does not solely reflect the coarse-grained nature of the deposits as samples of the similarly coarse-grained Mb. 5 behave distinctively. The more mafic composition of the latter marks the resumption of a preglacial signal, which was never totally cut off during the glaciation as shown by some specific samples in Mbs $1 \& 4$, the composition of which echoes the one of the preglacial deposits.

\subsection{Insights from $U-T h-P b$ datings}

The U-Th-Pb LA-ICPMS measurements were performed on 881 detrital zircon grains from the nine samples of the Tazekka section. Probability plots in Fig. 5 only include ages with a concordance between 95 and 105\%. One additional probability plot from the glacigenic sediments of the westernmost Meseta (NF01) is also given (Fig. 6B), to compare with the ages from a middle-upper Cambrian sandstone of the same area (15DL12; Letsch et al., 2018; Fig. 6B). The compilation of the 881 ages of the Tazekka section (Fig. 6C) shows a very similar age distributions for the $50-100 \mu \mathrm{m}$ and $100-250$ $\mu \mathrm{m}$ grain-size ranges, which indicates that hydraulic processes did not significantly impact our zircon record. It is apparent from Figs. 5 and 6C that Cryogenian-Ediacaran (Pan-African, 580720 Ma; Ennih and Liégeois, 2001; Gasquet et al., 2008) and Paleoproterozoic (Eburnean, 1790-2300 Ma, Abati et al., 2012) ages dominate the record. The two

243 populations, and the lull in between, which corresponds to the West African magmatic 244 gap of Linnemann et al. (2011), are regarded as a signature of the western segment of 245 the north Gondwana platform. Except sample Tf 3 showing the greatest ratio of Pan246 African to Eburnean zircon grains (59 vs. 24\%), which is comparable to most of previous 247 published works (Linnemann et al., 2011; Avigad et al., 2012; Gärtner et al., 2017), the 


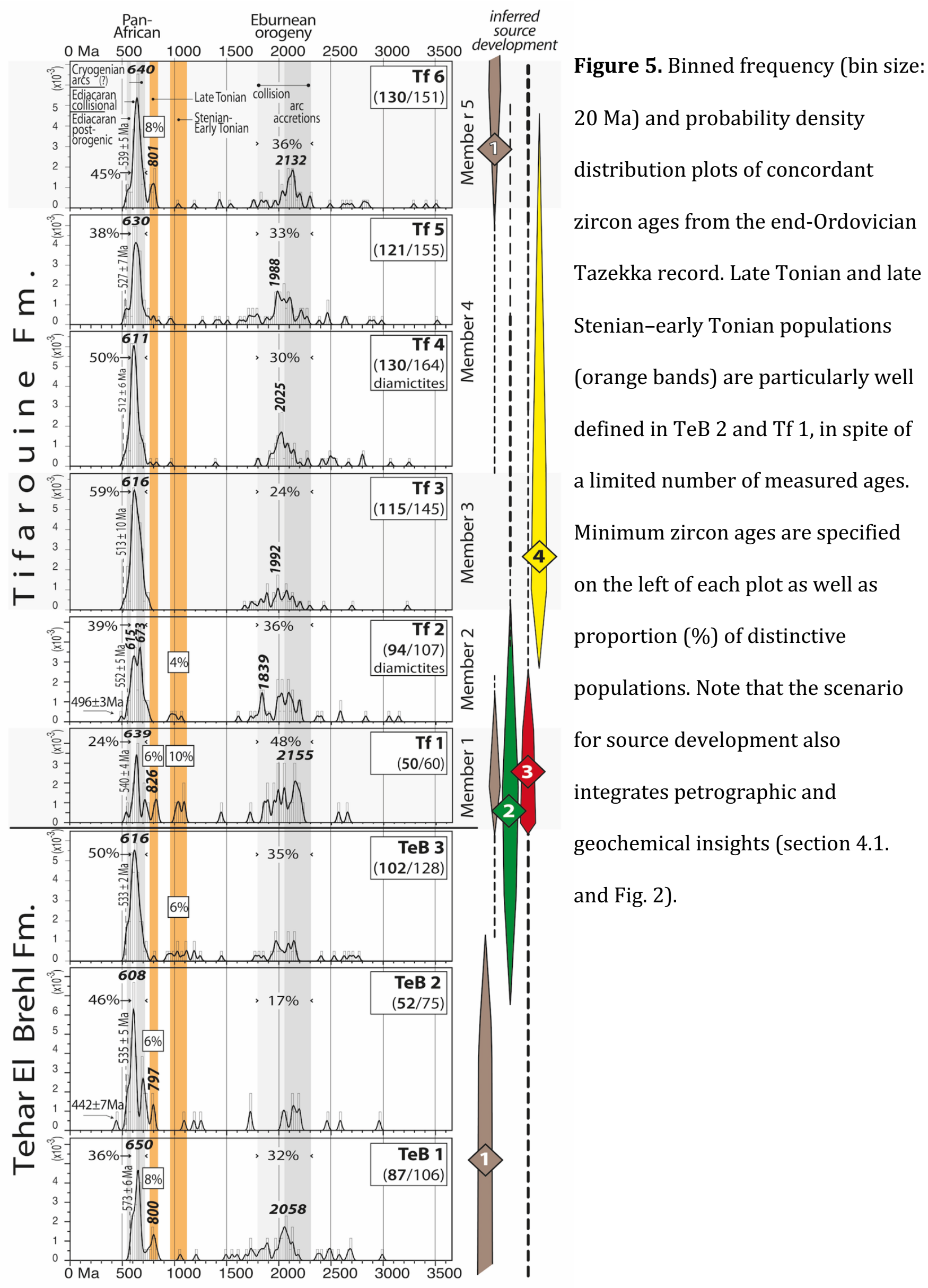




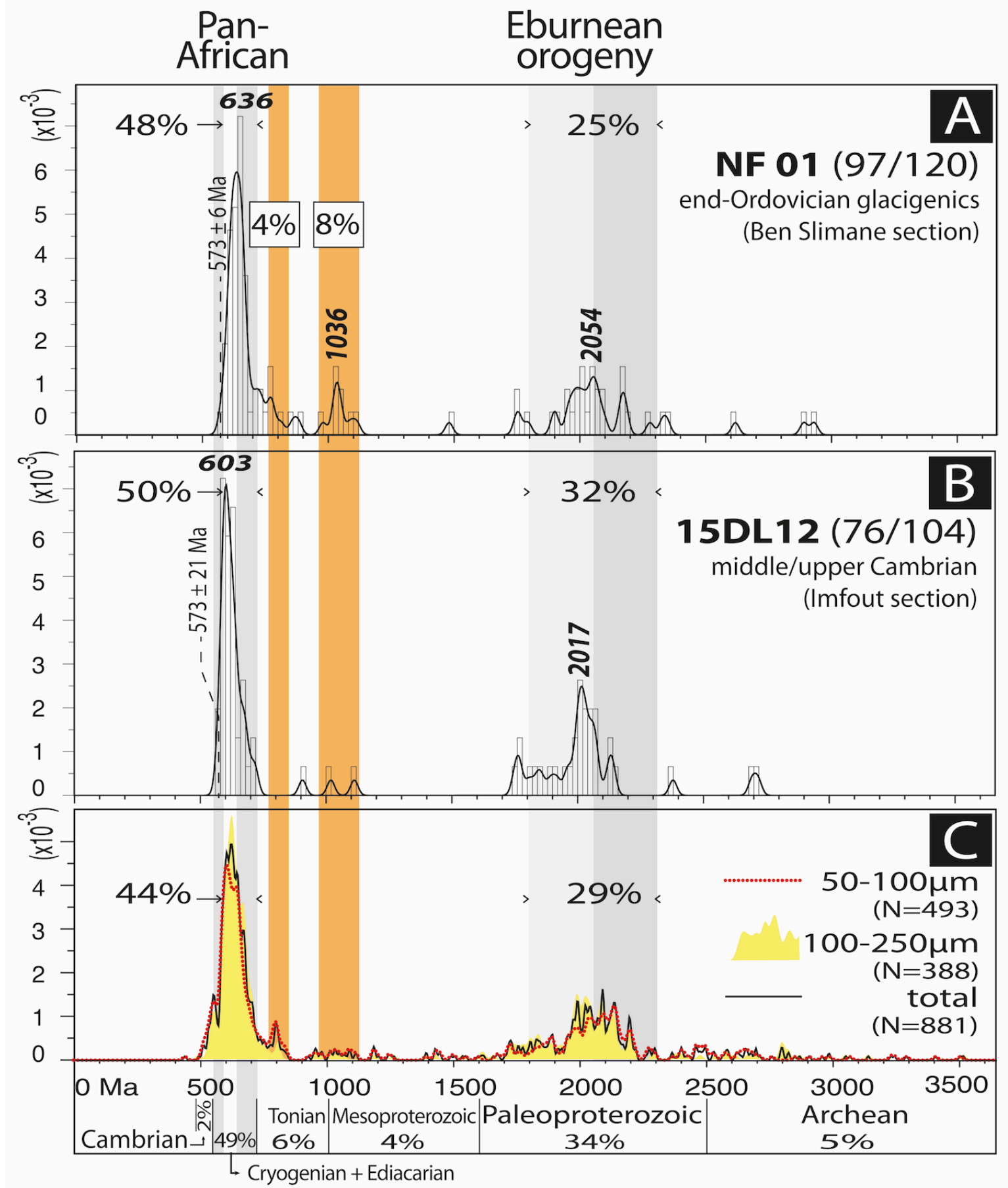

Figure 6. A \& B: Binned frequency (bin size: $20 \mathrm{Ma}$ ) and probability density distribution plots of concordant zircon ages from samples of the westernmost Meseta ('Coastal Block', located by the black star in Fig. 1), either (A) glacigenic deposits of the Ben Slimane section (this study) or (B) middle-upper Cambrian strata, El Hank Fm., Imfout section (modified from Letsch et al., 2018). C: age compilation of the 881 zircon ages of the Tazekka section plotted in Fig. 5. Orange bands refer to the late Tonian and late Stenian-early Tonian population discussed in the text. Grey bands in Pan-African ages, see Fig. 5. 
other glacigenic samples have a notable proportion of Eburnean zircon grains and sample Tf 1 yields significantly more Eburnean (48\%) than Pan-African (24\%) zircon grains.

Several Archean and Cambrian zircon grains were also detected, the latter being absent from the westernmost Meseta (Fig. 6). Post-orogenic Late Ediacaran zircon grains form a restricted population (<8\%), which peaks at 554Ma (Fig. 6C), yet it is most often identifiable in the form of a shoulder rather than an actual peak in individual plots (Fig. 5). Most interesting are two subordinate but distinctive populations: a late Tonian population, ranging from 840 to $760 \mathrm{Ma}$, and a late Stenian-early Tonian population showing a broader age cluster, ca. 960-1120 Ma ( 1 Ga; Fig. 5). The latter, best observed in sample Tf 1, is also well defined in NF01. These two age populations, though their presence/absence characterizes and differentiates some samples in this study (Fig. 5), appear poorly detectable in the age compilation (Fig. 6C).

\section{Discussion}

\subsection{Deciphering sediment sources.}

The fact that the westernmost Meseta zircon record is similar to that of the deeperwater Tazekka succession is in line with the northeastward $\left( \pm 45^{\circ}\right)$ orientation of shelf progradation across the Meseta during the Ordovician (Razin et al., 2002). However, latest Ediacaran-early Cambrian zircon grains throughout the Tifarouine Fm., absent from NF01 and 15DL12, suggest that the Tazekka watershed was not restricted to the Meseta. This is corroborated by the great thickness of the glacigenic succession $(>350$ m), largely exceeding that of other coeval peri-Gondwanan records that are generally no more than a few tens of metres in thickness (Chatalov, 2017 and references therein). The Tazekka was connected to the West African dispersal system and its relatively 
273 isolated current location at the NE tip of Western Meseta (Michard et al., 2010) cannot

274 be fully representative of the Lower Paleozoic configuration.

The overall Tazekka record combining sedimentology, geochemistry and insights

276 from zircon populations is best understood in terms of the interplay of four sources that

277 can be inferred for the Ordovician in and around Morocco (Figs. 2 and 5). Preglacial

278 Source 1 has a less mature composition and includes the late Tonian zircon population

279 (TeB 1 and TeB 2). Sample TeB 3 shows the cut-off of Source 1 or, more probably, its

280 dilution by Source 2, which is marked by the $\sim 1$ Ga zircon population. Associated with

281 the onset of sandstone deposition in the uppermost preglacial sediments, Source 2 also

282 characterizes the glacigenic deposits of the westernmost Meseta (Fig. 6). Source 3 is

283 inferred from the Tf 1 and Tf 2 record, typified by a great proportion of Eburnean zircon

284 grains. In Mb 1, at the base of the Tifarouine Fm., the late Tonian (i.e. 840-760 Ma) and

$285 \sim 1$ Ga populations are well defined, suggesting that sources 1 and 2 were still active,

286 either directly, or indirectly through the reworking of older strata. Source 4 (Tf 3) shows

287 the most mature composition (Mb. 3 in Figs 3 and 4), the greatest Pan-African zircon

288 grains, the younger Cambrian zircon population, a striking West African magmatic gap

289 - no more Mesoproterozoic zircon grains in discordant ages — and no Tonian zircon

290 grains. The overlying glacimarine interbed (Tf 4) mainly shares similar features. Due to

291 its association with the coarsest unit (Mb. 3), Source 4 is regarded as linked to the

292 maximum advance of the end-Ordovician glaciers in NW Africa. It may have been

293 activated slightly earlier in the succession, considering that the compositional signature

294 of the sandstone filling in the channels of the glaciomarine depositional system (Mb. 2)

295 is similar to that of Mb. 3 (see above; Figs. 3C \& 4B). In the upper part of the Tifarouine

296 Fm., samples Tf 5 and Tf 6 show the re-appearence of Mesoproterozoic zircon grains and

297 the progressive re-increase of the Eburnean zircon population. Further, a recurrence of 
Source 3:

\section{Tindouf Basin}

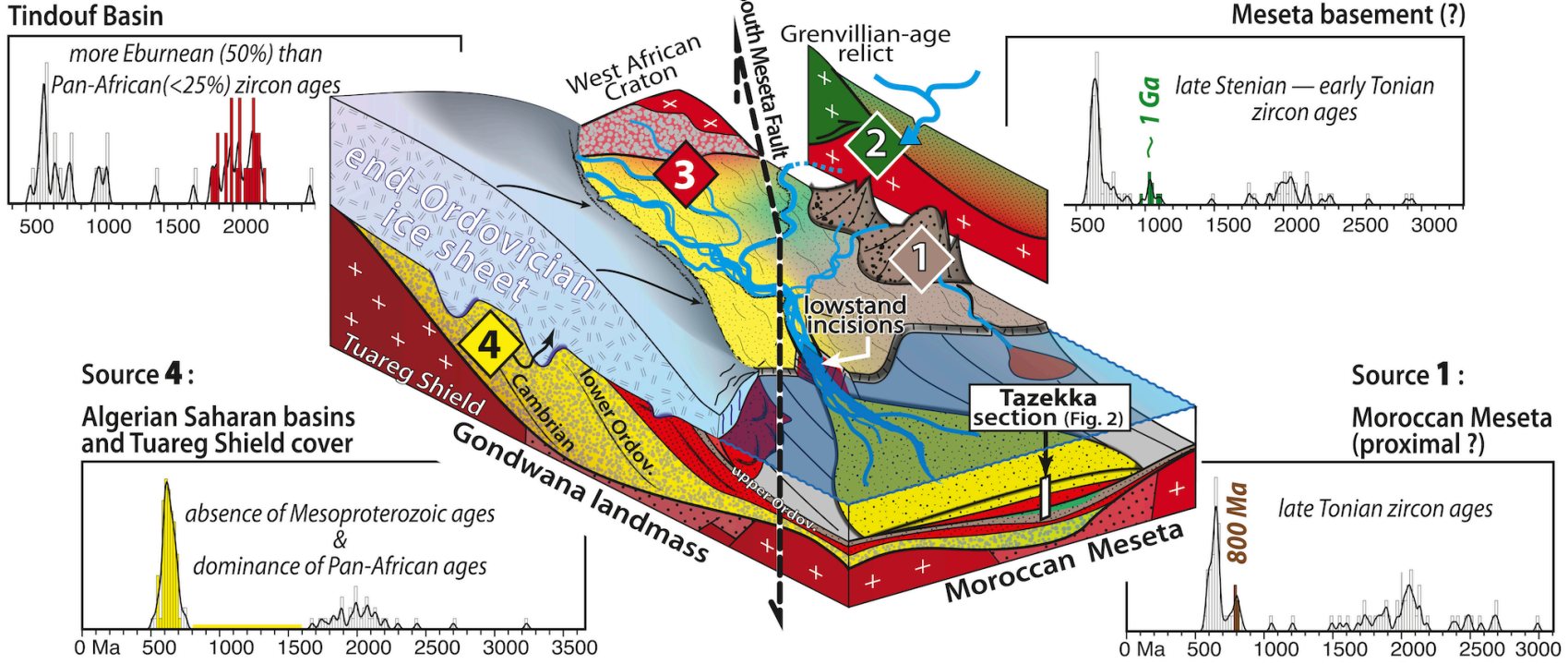

Figure 7. Conceptual model for glaciation-impacted sediment dispersal trends as understood from the Tazekka record. Patterns and colours as in Fig. 1. Numbers in diamonds relate to provenances discussed in the text (see also Fig. 2), the proposed location of which is given in Fig. 1. Probability plots selected from Figs. 5 and 6 illustrate the zircon age records tied to individual sources that together mixed and fed the Tazekka depocenter. Source 4 originates from glacial erosion of the CambrianOrdovician sedimentary cover (Algerian basins, Tuareg Shield cover), while other sources, of more local origin, may have involved a significant contribution of lowstand cannibalisations (fluvial incisions, shelf-margin canyons) and restricted truly glacigenic inputs. 
the late Tonian population is recognized in $\mathrm{Tf} 6$ (Fig. 5). It reflects the progressive upwards dilution of Source 4 understood as a recovery stage after the glaciation maximum. This is in line with slightly more mafic compositions noted in Mb. 5 samples,

301 a reminiscence of a signal observed in preglacial samples of the Tehar el Brehl Fm. (Fig. 3C). The last glacial advance, marked by renewed coarse-grained sedimentation in $\mathrm{Mb}$. 5 , remobilized a material dominated by Source 1 . As sediment sources are suspected to continuously mix through time, none of the probability plots (Figs 5 and 6) is so far fully representative of one particular provenance. Four of them, which can be regarded as typifying each of the four proposed provenances, are however used in Figure 7 to approximate, or at least illustrate, the zircon age records tied to individual sources that together fed the Tazekka depocenter.

\subsection{Sediment sources and glaciation development}

The scenario of sediment source development through the Tazekka stratigraphic record, representing only a ca. 5 Myr time span, is understood in the framework of the end-Ordovician glaciation. In addition, the regional-scale source diversity arisen from

314 the complex Lower Paleozoic evolution around the Meseta domain during peri-

315 Gondwana rifting events should be considered. Source 1 in preglacial sediments shows a 316 contribution of first-cycle clastic sediments, potentially in relation with a single Upper 317 Ordovician zircon recovered in TeB 2. We suspect a genetic link with a coeval thermal 318 event (Clauer et al., 1995) and the local denudation of Ediacaran basement rocks (Tahiri 319 et al., 2010) (Fig. 7), both possibly related to the magmatic (e.g., Caroff et al., 2009) 320 and/or extensional events (e.g., Martinez-Catalan et al., 1992) affecting the north321 Gondwana domain at the end of the Ordovician. The late Tonian population, which is 322 absent from sample 15DL12 from Cambrian strata of Coastal Meseta (Letsch et al., 2018; 
323 Fig. 6), reflects the erosion of rocks exposed only after the Cambrian, which are possibly

324 in relation with uplifts tied to the opening of Rheic ocean (Ouanaimi et al., 2016; Gärtner

325 et al., 2017). The paucity of Cambrian zircon grains indicates that (i) Cambrian rift

326 basins (Pouclet et al., 2008; Michard et al., 2010; Letsch et al., 2018) were buried at that

327 time, and (ii) the Eburnean basement of the Meseta cannot be considered as a source for

328 Paleoproterozoic zircon ages (e.g., El Houicha et al., 2018).

329 Source 2, activated prior to the onset of massive sandstone deposition in the

330 Tazekka, and relatively well-defined in the westernmost Meseta (Fig. 6A), suggests that

331 the $\sim 1$ Ga zircon population reflects the activation of a nearby source. Indeed, $\sim 1 \mathrm{Ga}$

332 zircon grains do not represent contribution of a more southern remote source, which

333 would have had a wider age spectrum regarding Mesoproterozoic ages (De Waele et al.,

334 2015; Gärtner et al., 2017). Combined with other 1 Ga ages documented in the

335 Moroccan context (a charnockite outcrop off Morocco, Michard et al., 2010; recycled

336 zircon in Ediacarian granites, Tahiri et al., 2010; recycled zircon in Trias volcanics,

337 Marzoli et al., 2017), Source 2 highlights the existence a currently undefined relict of

338 Grenvillian-aged crust. The latter has sourced, most likely from the west, directly

339 (erosion of Mesoproterozoic rocks) or indirectly (erosion of late Neoproterozoic

340 magmatic rocks having recycled Mesoproterozoic zircon), the end-Ordovician Moroccan

341 glacial dispersal system (Fig. 7), independently from other well-known sources related

342 to the largely more eastern Saharan metacraton (e.g., Meinhold et al., 2013; Henderson

343 et al., 2015). This ca. 1 Ga zircon population may derived from an exotic terrane issuing

344 from an Avalonian crust and later accreted, during the Pan-African and/or Cadomian

345 developments, to the West African Craton (Abbo et al., 2015; Marzoli et al., 2017;

346 Gärtner et al., 2017). The ca. 1 Ga zircon population, predating the massive arrival of 
glacigenic sediments, is not introduced in the Moroccan context by the end-Ordovician glaciation (see discussion in Pratt et al., 2015).

Source 3 is tied to the onset of mature glaciation-related deposits (Mb. 1), yet it was continuously providing sediments as shown by the great proportion of Eburnean zircon grains in the overall Tazekka record (Fig. 6C). In Mb. 1 of the glacigenic Tifarouine Fm., both the high Hf content that reflects the reworking of coastal placers, and the lack of evidence for any glacial depositional processes, suggest the local remobilisation of an older shelf succession; the later yielding a prevalent Eburnean population. The Source 3 signal is absent, or at least subordinate, in the westernmost Meseta (Fig. 6). It points to a southern derivation of material tied to the recycling of Cambrian-Ordovician strata of the Tindouf Basin, which themselves have been initially sourced predominantly from an 358 Eburnean basement (Reguibat Shield; Fabre and Kazi-Tani, 2005; Fig. 1). Whether or not the Sources 2 and 3 have involved glacial erosions remains unclear. Additional work is needed to decipher if this sequence is related to watershed reorganisations, including 361 meltwater captures and then glacigenic sediments, or to strictly localized lowstand cannibalizations (e.g., incised valley or shelf-margin canyon; Fig. 7).

364 Fm.) were principally fed from outside the Meseta and are tied to a fourth provenance.

365 Source 4 provides evidence for a major remobilization of the Cambrian-Ordovician

366 strata from the northern Saharan Basins or of the ancient cover of the Tuareg Shield 367 (Fabre and Kazi-Tani, 2005), the age spectrum of which (Linnemann et al., 2011) is very 368 similar to sample Tf 3. Source 4 is thus viewed as the signature of the NW-oriented ice 369 flows recognized in the Anti-Atlas (Fig. 1), and originating from the surroundings of the 370 current Tuareg Shield, where glacial downcuttings essentially eroded the Cambrian371 Ordovician cover, and more rarely the Pan-African rocks of the Trans-Saharan Belt (Fig. 
372 7; Fekirine and Abdallah, 1998; Ghienne et al., 2007b; Deschamps et al., 2013). The flux

373 of $>2.3$ Ga zircon grains detected upstreamward (Linnemann et al., 2011), which is

374 unrecognized in the Tazekka sequence, is suspected to correspond to a local and

375 transient input, rapidly redistributed by postglacial transgressive systems (cf. HOG6 and

376 HOG7 probability plots of Linnemann et al., 2011). Coarse-grained sediments of Mb. 5,

377 compositionally slightly less mature and showing a renewed contribution of Source 1,

378 suggest that the last glacial advance reworked a great proportion of local material, most

379 likely including earlier end-Ordovician glacigenics, with a fading contribution of Source

380 4. Mb. 5 is tentatively linked with glaciers that, in the Anti-Atlas, flowed from the W

381 (Dietrich et al., in press).

382

\section{6. Conclusions}

384 The Tazekka glacigenic deposits essentially derived from the cannibalization of the 385 "great Lower Paleozoic quartz-rich sandstone sheet", itself initially having recycled the 386 Pan-African molasse and flysch basins (Avigad et al., 2017), rather than recording a 387 pulse of fresh, far-travelled, first-cycle clastic sediments issuing from basement rocks. 388 This finding is in line with conclusions of Chatalov (2017) and Gärtner et al. (2017), also 389 dealing with the north Gondwana area but is in contrast with common views about the 390 limited maturity of syn-glaciation deposits (Nesbitt and Young, 1982; Yan et al., 2010;

391 Bahlburg and Dobrzinski, 2011; Huang et al. 2014). More interestingly, end-Ordovician 392 glacigenic deposits in South Africa show a significantly lower CIA than that of the 393 underlying preglacial succession (Young et al., 2004), which is in contrast to the north394 Gondwanan examples from this study, even regarding the diamictite samples (Fig. 3A). 395 It might suggest two distinct modes of glacial erosion, involving eroding highlands in the 
first case, essentially recycling the preglacial shelf sediments in the second case, with potential contributions from remote highlands absent or greatly diluted. Glacial erosion of the Cambrian-Ordovician strata, especially during the glacial maximum, boosted the transfer of compositionally -i.e., mineralogically and geochemically — mature material toward the continental margin, temporarily masking regional signals expressed only before the glaciation or in its earlier stages (late Tonian and late Stenian-early Tonian zircon ages, respectively). The glacial maximum was responsible for a notable provenance change of a broader significance which may be traceable outside Morocco, rather than just be a result of local adjustments. The firstorder, continental-scale Lower Paleozoic dispersal trends nevertheless pertained through the glaciation. They were buffered by the voluminous, north-African Lower Paleozoic sandstones that furnished the main contribution to the glacigenic material, which consequently show more mature compositions than those prevailing in Morocco prior to the end-Ordovician glaciation.

\section{ACKNOWLEDGEMENTS}

The authors are thankful to Dov Avigad, N. Eyles and an anonymous reviewer, whose comments greatly contributed to the improvement of the original manuscript. This work is a contribution to the SeqStrat-Ice ANR project 12-BS06-14. It was partly funded by the joined industry project GRASP (University of Geneva), the Fondation Lombard (Geneva), and the Czech Ministry of Education, Youth and Sports (project LK11202). We are grateful to Patricie Halodová for help with cathodoluminiscence imaging. 


\section{REFERENCES}

422 Abati, J., Aghzer, A.M., Gerdes, A., and Ennih, N., 2012. Insights on the crustal evolution of 423 the West African Craton from Hf isotopes in detrital zircons from the Anti-Atlas belt. 424 Precambrian Research 212-213, 263-274.

425

426

Abbo, A., Avigad, D., Gerdes, A. and Güngör, T., 2015. Cadomina basement and Paleozoic to Triassic siliciclastics of the Taurides (Karacahisar dome, south-central Turkey): Paleogeographic constraints from U-Pb-Hf in zircons. Lithos 227, 122-139.

Andersen, T., Kristoffersen, M., and Elburg, M.A., 2016. How far can we trust provenance and crustal evolution information from detrital zircons? A South African case study. Gondwana Research 34, 129-148.

Avigad, D., Gerdes, A., Morag, N., and Bechstädt, T., 2012. Coupled U-Pb-Hf of detrital zircons of Cambrian sandstones from Morocco and Sardinia: Implications for provenance and Precambrian crustal evolution of North Africa. Gondwana Research,

$$
21,690-703 .
$$

Avigad, D., Morag, N., Abbo, A., and Gerdes, A., 2017. Detrital rutile U-Pb perspective on the origin of the great Cambro-Ordovician sandstone of North Gondwana and its linkage to orogeny. Gondwana Research 51, 17-29.

Bahlburg, H., and Dobrzinski, N., 2011. A review of the Chemical Index of Alteration (CIA) and its application to the study of Neoproterozoic glacial deposits and climate transitions. In: Arnaud, E. et al. (Eds.), The Geological Record of Neoproterozoic Glaciations, pp. 81-92 Geological Society London, Memoirs.

Caroff, M., Vidal, M., Bénard, A., and Darboux, J.-R., 2009. A late-Ordovician phreatomagmatic complex in marine soft-substrate environment: The Crozon 
volcanic system, Armorican Massif (France). Journal of Volcanology and Geothermal

$445 \quad$ Research 184, 351-366.

446 Chatalov, A., 2017. Sedimentology of Hirnantian glaciomarine deposits in the Balkan

447 Terrane, western Bulgaria: Fixing a piece of the north periGondwana jigsaw puzzle.

448 Sedimentary Geology 350, 1-22.

449 Chelle-Michou, C., Laurent, O., Moyen, J.-F., Block, S., Paquette, J.-L., Couzinié, S., Gardien, 450 V., Vanderhaeghe, O., Villaros, A., and Zeh, A., 2017. Pre-Cadomian to late-Variscan 451 odyssey of the eastern Massif Central, France: Formation of the West European crust 452 in a nutshell. Gondwana Research 46, 170-190.

453 Chopin, F., Corsini, M., Schulmann, K., El Houicha, M., Ghienne, J.-F. and Edel, J.-B., 2014. 454 Tectonic evolution of the Rehamna metamorphic dome (Morocco) in the context of 455 the Alleghanian-Variscan orogeny. Tectonics 33, 1154-1177.

456 Clauer, N., Rais, N., Schaltegger, U., and Piqué, A., 1995. K-Ar systematics of clay-to-mica 457 minerals in a multi-stage low-grade metamorphic evolution. Chemical Geology 124, $458 \quad 305-316$.

459 Deschamps, R., Eschard, R., and Roussé, S., 2013. Architecture of Late Ordovician glacial 460 valleys in the Tassili N'Ajjer area (Algeria). Sedimentary Geology 289, 124-147.

461 De Waele, B., Lacorde, M., Vergara, F., and Chan, G., 2015. New insights on Proterozoic 462 tectonics and sedimentation along the peri-Gondwanan West African margin based 463 on zircon U-Pb SHRIMP geochronology. Precambrian Research 259, 156-175.

464 Dietrich, P., Ghienne, J.-F., Lajeunesse, P., Deschamps, R., Normandeau, A., Razin, P., in 465 press. Deglacial sequences and glacio-isostatic adjustment. Quaternary compared 466 with Ordovician glaciations. In: Glaciated Margins: The Sedimentary and Geophysical 467 Archives, D. Le Heron et al. (Eds), Geological Society London, Spec. Publ. 475. 
468 Doornbos, C., Heaman, L.M., Doupé, J.P. , England, J., Simonetti, A., and Lajeunesse, P., 469 2009. The first integrated use of in situ U-Pb geochronology and geochemical 470 analyses to determine long-distance transport of glacial erratics from mainland 471 Canada into the western Arctic Archipelago. Canadian Journal of Earth Science 46, $472 \quad 101-122$.

473 El Houicha, M., Peirera, M.F., Jouhari, A., Gama, C., Ennih, N., Fekkak, A., Ezzouhairi, H., El 474 Attari, A., and Silva, J.B., 2018. Recycling of the Proterozoic crystalline basement in the 475 Coastal Block (Moroccan Meseta): New insights for understanding the geodynamic 476 evolution of the northern peri-Gondwanan realm. Precambrian Research 306, 129$477 \quad 154$.

478 Fabre, J., and Kazi-Tani, N. 2005. Ordovicien, Silurien, Devonien, Permo-Carbonifère, 479 147-360. In : Fabre, J. (Ed.) Géologie du Sahara occidental et central, Tervuren African 480 Geoscience Collection 18, Musée Royal de l'Afrique Centrale, Tervuren, Belgium. 481 Fedo, C. M., Nesbitt, H. W., and Young, G. M., 1995. Unraveling the effects of potassium 482 metasomatism in sedimentary rocks and paleosols, with implications for 483 paleoweathering conditions and provenance. Geology 23, 921-924.

484 Fekirine, B., and Abdallah, H., 1998. Palaeozoic lithofacies correlatives and sequence 485 Stratigraphy of the Sahara Platform, Algeria. In: Maccregor, D.S., Moody, R.T.J., Clark486 Lowes, D.D. (Eds.) ,Petroleum Geology of North Africa. Pp. 97-108. Geological Society 487 London Special Publication 132.

488 Floyd, P.A., and Leveridge, B.E., 1987. Tectonic environment of the Devonian Gramscatho 489 bason, south Cornwall : Framework mode and geochemical evidence from turbiditic 490 sandstones. Journal of the Geological Society 144, 531-542. 
491 Fralick, P. W., 2003. Geochemistry of clastic sedimentary rocks: ratio techniques. In:

492 Lentz, D. R. (Ed.): Geochemistry of Sediments and Sedimentary Rocks: Evolutionary 493 Considerations to Mineral Deposit-Fanning Environments. Geological Association of 494 Canada, GeoTexl 4.

495 Gärtner, A., Youbi, N., Villeneuve, M., Sagawe, A., Hofmann, M., Mahmoudi, A., Boumehdi, 496 M.A., and Linnemann, U., 2017. The zircon evidence of temporally changing sediment 497 transport—the NW Gondwana margin during Cambrian to Devonian time (Aoucert 498 and Smara areas, Moroccan Sahara). International Journal of Earth Sciences 106, $499 \quad 2747-2769$.

500 Gasquet, D., Ennih, N., Liegeois, J. P., and Michard, A., 2008. The Pan-African Belt. 501 Continental evolution. The geology of Morocco: Structure, Stratigraphy, and Tectonics 502 of the Africa-Atlantic-Mediterranean Triple Junction, pp. 33-64 Springer Verlag 503 Berlin, Heidelberg.

504 Ghienne, J.-F., Le Heron, D., Moreau, J., Denis, M., and Deynoux, M. 2007a. The Late 505 Ordovician glacial sedimentary system of the North Gondwana platform. In: Hambrey, 506 M., Christoffersen, P., Glasser, N., Janssen, P., Hubbard, B., Siegert, M (Eds.), Glacial 507 Sedimentary Processes and Products. pp. 295-319 Internal Association of 508 Sedimentologists, Special Publication 39.

509 Ghienne, J.-F., Boumendjel, K., Paris, F., Videt, B., Racheboeuf, P., and Salem, H.A., 2007b. 510 The Cambrian-Ordovician succession in the Ougarta Range (western Algeria, North 511 Africa) and interference of the Late Ordovician glaciation on the development of the 512 Lower Palaeozoic transgression on northern Gondwana. Bulletin of Geosciences 82, $513 \quad 183-214$. 
514 Ghienne, J.-F., Desrochers, A., Vandenbroucke, T.R.A., Achab, A., Asselin, E., Dabard, M.-

515 P.,Farley, C., Loi, A., Paris, F., Wickson, S., and Veizer, J., 2014. A Cenozoic-style

516 scenario for the end-Ordovician glaciation. Nature Communications 5, paper number

$517 \quad$ 4485, doi: 10.1038/ncomms5485.

518 Gürsu, S., Mueller, P.A., Sunkari, E.D., Möller, A., Köksal, S., Kamenov, G.D., and

519 Göncüoğlu, M.C., 2018. Nd, Pb, Hf isotope characteristics and provenance of glacial

520 granitic pebbles from Late Ordovician diamictites in the Taurides, S Turkey.

521 Gondwana Research 54, 205-216.

522 Henderson, B.J., Collins, W.J., Murphy, J.B., Gutierrez-Alonso, G., and Hand, M., 2015.

523 Gondwanan basement terranes of the Variscan-Appalachian orogen: Baltican,

524 Saharan and West African hafnium isotopic fingerprints. Tectonophysics $681,278-$

525304.

526 Hoepffner, C., Soulaimani, A., and Piqué, A., 2005. The Moroccan Hercynides. Journal of 527 African Earth Sciences 43, 144-165.

528 Hofmann, M., Linnemann, U., Hoffmann, K.H., Germs, G., Gerdes, A., Marko, L., Eckelmann, 529 K., Gärtner A., and Krause, R., 2015. The four Neoproterozoic glaciations of southern $530 \quad$ Namibia and their detrital zircon record: The fingerprints of four crustal growth 531 events during two supercontinent cycles. Precambrian Research 259, 176-188.

532 Huang, J., Feng, L., Lu, D., Zhang, Q., Sun, T., Chu, X. 2014. Multiple climate cooling prior to 533 Sturtian glaciations: Evidence from chemical index of alteration of sediments in South 534 China. Scientific Reports 4, 6868.

535 Jackson, S.E., Pearson, N.J., Griffin, W.L., and Belousova, E.A., 2004. The application of 536 laser ablation-inductively coupled plasma-mass spectrometry to in situ U-Pb zircon 537 geochronology. Chemical Geology 211, 47-69. 
538 Jackson, S., 2008. Lamtrace data reduction software for LA-ICP-MS. In: Sylvester, P. J.

539 (Ed.), Laser Ablation-ICP-MS in the Earth Sciences: Current Practices and Outstanding $540 \quad$ Issues, pp. 305-307 Mineralogical Association of Canada.

541 Jaffey, A.H., Flynn, K.F., Glendenin, L.E., Bentley, W.C., Essling, A.M., 1971. Precision 542 measurements of half-lives and specific activities of ${ }^{235} \mathrm{U}$ and ${ }^{238} \mathrm{U}$. Physical Reviews $\mathrm{C}$ $543 \quad 4,1889-1906$.

544 Le Heron, D., 2007. Late Ordovician glacial record of the Anti-Atlas, Morocco. 545 Sedimentary Geology 201, 93-110.

546 Le Heron, D., Ghienne, J.-F., El Houicha, M., Khoukhi, Y., and Rubino, J.-L, 2007. Maximum 547 extent of ice sheets in Morocco during the Late Ordovician glaciation. 548 Palaeogeography Palaeoclimatology Palaeoecology 245, 200-226.

549 Le Heron, D.P., Khoukhi, Y., Paris, F., Ghienne, J.-F. and Le Herissé, A., 2008 ; Black shale, 550 grey shale, fossils and glaciers: Anatomy of the Upper Ordovician-Silurian succession 551 in the Tazzeka Massif of eastern Morocco. Gondwana Research 14, 483-496.

552 Le Heron, D.P., and Craig, J., 2008. First-order reconstructions of a Late Ordovician 553 Saharan ice sheet. Journal of Geological Society 165, 19-29.

554 Letsch D., El Houicha M., von Quadt A., and Winkler, W.A., 2018. A missing link in the 555 peri-Gondwanan terrane collage: the Precambrian basement of the Moroccan Meseta 556 and its Lower Paleozoic cover. Canadian Journal of Earth Sciences 55, 33-51.

557 Linnemann, U., Ouzegane, K., Drareni, A., Hofmann, M., Becker, S., Gärtner, A., and 558 Sagawe, A., 2011. Sands of West Gondwana: An archive of secular magmatism and 559 plate interactions - A case study from the Cambro-Ordovician section of the Tassili 560 Ouan Ahaggar (Algerian Sahara) using U-Pb-LA-ICPMS detrital zircon ages. Lithos $561 \quad 123,188-203$. 
Loi, A., Ghienne, J.-F., Dabard, M.P. , Paris, F. , Botquelen, A., Christ, N., Elaouad-Debbaj, Z., Gorini, A., Vidal, M., Videt, B. and Destombes, J., 2010. The Late Ordovician glacioeustatic record from a high-latitude storm-dominated shelf succession: The Bou Ingarf section (Anti-Atlas, Southern Morocco). Paleogeography Paleoclimatology Paleoecology 296, 332-358.

Longerich, H. P., Jackson, S. E., and Gunther, D., 1996. Inter-laboratory note. Laser ablation inductively coupled plasma mass spectrometric transient signal data acquisition and analyte concentration calculation. Journal of Analytical Atomic

Ludwig, K.R., 2012. User's manual for Isoplot 3.75 : A geochronological toolkit for Microsoft Excel. Berkley Geochronology Center Special Publication No.5. Gonzalez Lodeiro, F., 1992. Lower Paleozoic extensional tectonics in the limit between the West Asturian-Leonese and Central Iberian Zones of the Variscan FoldBelt in NW Spain. Geologische Rundschau 81/2, 545-560. approaches to sedimentation, provenance, and tectonics. In: Johnsson, M. l. \& Basu, A. (Eds.), Processes Controlling the Composition of Clastic Sediments, pp. 21-40 Geological Society of America, Special Paper.

581 McLennan, S. M., Bock, B., Hemming, S., Hurowitz, J. A., Lev, S. M., and McDaniel , D. K., 582 2003. The role of provenance and sedimentary processes in the geochemistry of 583 sedimentary rocks. In Lentz, D. R. (ed.): Geochemistry of Sediments and Sedimentary 584 Rocks: Evolutionary Considerations to Mineral Deposit-Fanning Environments, pp. 7$585 \quad 38$ Geological Association of Canada, GeoTexl 4. 
Marzoli, A., Davies, J.H.F.L., Youbi, N., Merle, R., Dal Corso, J., Dunkley, D.J., Fioretti, A.M.,

587 Bellieni, G., Medina, F., Wotzlaw, J.-F., McHone, G., Font, E. and Bensalah, M.K., 2017.

588 Proterozoic to Mesozoic evolution of North-West Africa and Peri-Gondwana

589 microplates: detrital zircon ages from Morocco and Canada. Lithos 278-281, 229-239.

590 Meinhold, G., Morton, A.C., Avigad D., 2013. New insights into peri-Gondwana

591 paleogeography and the Gondwana super-fan system from detrital zircon U-Pb ages.

592 Gondwana Research 23, 661-665.

593 Michard, A., Soulaimani, A., Hoepffner, C., Ouanaimi, H., Baidder, L., Rjimati, E.C., and 594 Saddiqi, O., 2010. The south-western branch of the Variscan belt: Evidence from $595 \quad$ Morocco. Tectonophysics 492, 1-24.

596 Nesbitt, H., W., 2003. Petrogenesis of siliciclastic sediments and sedimentary rocks. In:

597 Lentz, D. R. (Ed.): Geochemistry of Sediments and Sedimentary Rocks: Evolutionary

598 Considerations to Mineral Deposit-Forming Environments, pp. 39-51 Geological 599 Association of Canada, GeoText 4

600 Nesbitt, H. W., and Young, G. M., 1982. Early Proterozoic climates and plate motions 601 inferred from major element chemistry of lutites. Nature 299, 715-717.

602 Ouanaimi H., Soulaimani A., Hoepffner C., Michard A., and Baidder L., 2016. The Atlas603 Meseta Red Beds basin (Morocco) and the Lower Ordovician rifting of NW604 Gondwana. Bulletin de la Société Géologique de France 187, 155-168.

605 Paton, C., J. D. Woodhead, J. C. Hellstrom, J. M. Hergt, A. Greig, and R. Maas, 2010.

606 Improved laser ablation $\mathrm{U}-\mathrm{Pb}$ zircon geochronology through robust downhole 607 fractionation correction. Geochemistry Geophysics. Geosystems 11, paper number 608 Q0AA06, doi:10.1029/2009GC002618. 
609 Pastor-Galán, D., Gutiérrez-Alonso, G., Murphy, J.B., Fernández-Suárez, J., Hofmann, M.,

610 and Linnemann, U., 2013. Provenance analysis of the Paleozoic sequences of the

611 northern Gondwana margin in NW Iberia: passive margin to Variscan collision and

612 orocline development. Gondwana Research 23, 1089-1103.

613 Pérez-Càceres, I., Poyatos, D.M., Simancas, J.F., and Azor, A., 2017. Testing the Avalonian

614 affinity of the South Portuguese Zone and the Neoproterozoic evolution of SW Iberia

615 through detrital zircon populations. Gondwana Research 42, 177-192.

616 Pistis, M., Loi, A. and Dabard, M.-P, 2016. Influence of relative sea-level variations on the 617 genesis of palaeoplacers, the examples of Sarrabus (Sardinia, Italy) and the

618 Armorican Massif (western France). Comptes Rendus Geosciences 348, 150-157.

619 Pohl, A., Donnadieu, Y., Le Hir, G., Ladant, J.B., Dumas, C., Alvarez-Solas, J. and

620 Vandenbroucke, T.R.A., 2016. Glacial onset predated Late Ordovician climate cooling,

$621 \quad$ Paleoceanography $31,800-821$.

622 Pouclet, A., Ouazzani H., and Fekkak A., 2008. The Cambrian volcano-sedimentary

623 formations of the westernmost High Atlas (Morocco): Their place in the geodynamic

624 evolution of the West African Palaeo-Gondwana northern margin. In: Ennih N.,

625 Liégeois J.-P. (Eds): The Boundaries of the West African Craton, Geological Society

$626 \quad$ London, Spec. Publ 297, 303-327.

627 Pratt, J.R., Barbeau, D.L.Jr., Garver, J.I., Emran, A., and Izykowski, T.M., 2015. Detrital 628 zircon geochronology of Mesozoic sediments in the Rif and Middle Atlas Belts of 629 Morocco: Provenance constraints and refinement of the West African signature. $630 \quad$ Journal of Geology 123, 177-200.

631 Ravier, E., Buoncristiani, J. F., Menzies, J., Guiraud, M., Clerc, S., and Portier, E., 2015. Does 632 porewater or meltwater control tunnel valley genesis? Case studies from the 

376.

635

636

Razin, P., Baudin, T., Chevremont, P., Andies, D., Youbi, N., Hoepffner, C., Thieblemont, D., and Chichani, E.-M., 2002. Carte Géologique 1/50000, Jebel Kharrou. Notes et Mémoires du Service Géologique du Maroc 436 bis, 104 pp.

Rognon, P., Biju-Duval, B., and De Charpal, O., 1972. Modelés glaciaires dans l'Ordovicien supérieur saharien: phases d'érosion et glaciotectonique sur la bordure nord des Eglab. Revue de Géographie Physique et Dynamique 14, 507-528.

Roser, B.P. and Korsch, R.J., 1988. Provenance signatures of Sandstone-mudstone suites determined using discriminant function analysis of major-elment data. Chemical Geology 67, 119-139.

Shaw, J., Gutiérrez-Alonso, G., Johnston, S. T. and Galán, D. P. 2014. Provenance variability along the Early Ordovician north Gondwana margin: Paleogeographic and tectonic implications of U-Pb detrital zircon ages from the Armorican Quartzite of the Iberian Variscan belt. Geological Society of America Bulletin 126, 702-719.

Sláma, J., Košler, J., Condon, D.J., Crowley, J.L., Gerdes, A., Hanchar, J.M., Horstwood, M.S.A., Morris, G.A., Nasdala, L., Norberg, N., Schaltegger, U., Schoene, N., Tubrett, M.N., and Whitehouse, M.J., 2008. Plešovice zircon - a new natural reference material for U$\mathrm{Pb}$ and Hf isotopic microanalysis. Chemical Geology 249, 1-35.

Tahiri, A., Montero P., El Hadi H., Martínez Poyatos D., Azor A., Bea F., Simancas J.F., and González Lodeiro, F., 2010. Geochronological data on the Rabat - Tiflet granitoids: Their bearing on the tectonics of the Moroccan Variscides. Journal of African Earth Sciences $57,1-13$. 
656 Taylor, S.R., and McLennan, S.M., 1985. The continental crust: Its composition and 657 evolution. Blackwell Scientific Pub., Palo Alto, CA, United States.

658 Wedepohl, H.K., 1995. The composition of continental crust. Geochimica Et 659 Cosmochimica Acta 59, 1217-1232.

660 Wiedenbeck, M., Alle, P., Corfu, F., Griffin, W.L., Meier, M., Oberli, F., von Quadt, A., 661 Roddick, J.C., and Spiegel, W., 1995. Three natural zircon standards for U-Th-Pb, Lu662 Hf, trace element and REE analyses. Geostandards Newsletter 19, 1-23.

663 Yan, D., Chen, D., Wang, Q., and Wang, J., 2010. Large-scale climatic fluctuations in the 664 latest Ordovician on the Yangtze block, south China. Geology 38, 599-601.

665 Young, M.G., Minter, W.E.L., and Theron, J.N., 2004. Geochemistry and palaeogeography 666 of upper Ordovician glaciogenic sedimentary rocks in the Table Mountain Group, 667 South Africa. Paleogeography Paleoclimatology Paleoecology 214, 323-345. 